\title{
Penerapan Teori Konstruktivisme pada Pembelajaran Daring Interaktif
}

\author{
Yuni Budyastuti $^{1}$ \& Endang Fauziati $^{2}$
}

Universitas Muhammadiyah Surakarta, Indonesia

${ }^{\bowtie}$ E-mail: yunibudyastuti@gmail.com

\begin{abstract}
Abstrak
Penelitian ini bertujuan untuk memberikan gambaran tentang penerapan teori konstruktivisme yang terkait dengan pembelajaran daring interaktif di SMP Negeri 1 Pabelan. Metode penelitian yang digunakan adalah metode kualitatif dengan study pustaka. Subjek penelitian meliputi kepala sekolah, guru mata pelajaran kelas VIII, dan siswa kelas VIII sebanyak 32 siswa. Teknik pengumpulan data yaitu dengan observasi, dan wawacara. Hasil dari penelitian ini, siswa dapat mengonstruksi pemahamannya melalui pembelajaran daring dengan berbantuan media whatsapp seperti mengajukan pertanyaan melalui chat, atau voice note, mengerjakan tugas secara langsung melalui share link dari guru, memberikan feedback atau koreksi ke siswa dengan melampirkan bukti screenshoot, dan menyimpulkan materi secara bersama-sama dengan meminta siswa mengirimkan foto hasil rangkuman materi dan dibagikan pada chat grup, serta guru menambahkan, menjelaskan dengan disertai lampiran materi berupa doc, PPT, dan e-modul. Kesimpulan dari penelitian ini adalah melalui penerapan teori konstruktivisme dalam pembelajaran daring menunjukkan proses interaktif yang sangat baik antara guru dan siswa SMP Negeri 1 Pabelan.
\end{abstract}

Kata Kunci: Konstruktivisme; Pembelajaran Daring; 5M.

\begin{abstract}
This study aims to provide an overview of the application of constructivism theory related to interactive online learning at SMP Negeri 1 Pabelan. The research method used is a qualitative method with literature study. The research subjects included the principal, class VIII subject teachers, and 32 students of class VIII. Data collection techniques are by observation and interviews. The results of this study, students can construct their understanding through online learning with the help of whatsapp media such as asking questions via chat, or voice notes, doing assignments directly through a share link from the teacher, providing feedback or corrections to students by attaching screenshot evidence, and concluding the material. together by asking students to take a photo of the summary of the material and share it in group chats, and the teacher adds, explains along with material attachments in the form of docs, PPT, and e-modules. The conclusion of this research is that through the application of constructivism theory in learning, it shows a very good interactive process between teachers and students of SMP Negeri 1 Pabelan.
\end{abstract}

Keywords: Constructivism; Online Learning; 5M. 


\section{PENDAHULUAN}

Pembelajaran daring yang saat ini diterapkan dalam dunia pendidikan dikarenakan untuk membantu penekanan angka penyebaran Covid-19. Penerapan pembelajaran daring yang datang begitu mendadak tanpa persiapan, membuat para guru harus melakukan perubahan dalam pembelajaran. Pembelajaran tatap muka yang biasanya dilaksanakan menjadi pembelajaran daring atau online. Pelaksanaan pembelajaran di masa pandemi tentu akan mejadi pembelajaran baru dan bukan bersifat pembelajaran konvensional yang dipahami sampai saat ini.

Model pembelajaran konvensional itu sendiri, merupakan model pembelajaran yang masih digunakan dalam proses pembelajaran, hanya saja model pembelajaran konvensional saat ini sudah mengalami berbagai perubahan-perubahan karena tuntutan perkembangan zaman. Meskipun demikian tidak meninggalkan keasliannya (Ibrahim, 2017:202). Dewi (2018:46) menyatakan bahwa metode konvensional dalam pembelajaran adalah metode yang digunakan berdasarkan kecenderungan yang menjadikan guru dan siswa tidak pasif selalu belajar, berpikir dan inovatif. Sedangkan pembelajaran online mengacu pada proses pembelajaran, diskusi, bimbingan dan evaluasi yang dapat dilakukan dimana saja dan kapan saja tanpa adanya pertemuan langsung (Tuti dkk., 2020:195).

Perbedaan pembelajaran konvensional dan pembelajaran daring memunculkan metode yang inovatif, praktis, serta efisien dalam proses pembelajaran sesuai dengan keadaan yang dihadapi dunia pendidikan yang berubah-ubah. Dari kenyataan tersebut maka pembelajaran daring interaktif akan menggunakan teori konstruktivisme. Kontruksi artinya membangun, dalam konteks filsafat pendidikan, konstruktivisme adalah upaya untuk menegakkan tatanan kehidupan budaya modern. Konstruktivisme juga merupakan suatu paham (aliran) tentang bagaimana pengetahuan dapat dimiliki oleh seseorang (individual) dalam pikirannya atau dengan kata lain tentang bagaimana pengetahuan itu dapat dipelajari oleh seseorang. Oleh karena itu konstruktivisme juga dapat dianggap sebagai teori pembelajaran, karena pembentukan pengetahuan adalah oleh siswa itu sendiri, maka dalam belajar siswa harus aktif, berinteraksi, berpikir, dan mengembangkan ide dan peran pendidik adalah memfasilitasi agar siswa dapat belajar secara maksimal (Tahrun, 2021:35).

Teori menjadi penting bagi kemajuan dunia. Dalam pendidikan, teori menempati posisi strategis yang sangat penting, karena dengan perkembangan teori, pengetahuan dan pengalaman terus berkembang. Berbicara teori, ada banyak teori yang cocok untuk perkembangan dunia pendidikan, salah satunya adalah teori konstruktivisme (Suparlan, 2019:80). Kontruktivisme sebagai landasan pemikiran belajar konstektual (filsafat), yaitu bahwa pengetahuan dibangun oleh manusia sedikit demi sedikit, dan hasilnya adalah konteks yang terbatas dan bukan hadir dengan tiba-tiba. Pengetahuan bukanlah seperangkat fakta-fakta, konsep, kaidah yang siap untuk diambil dan diingat. Manusia harus membangun pengetahuan itu dan memberinya makna melalui pengalaman nyata.

Dalam pembelajaran daring, konstruktivisme diterapkan dalam proses pembelajaran agar siswa lebih aktif dalam kegiatan pembelajaran dan guru hanya sebagai fasilitator. Guru adalah orang yang berinteraksi langsung saat pembelajaran berlangsung, guru juga membuat rencana 
untuk mengevaluasi kegiatan. Guru memiliki banyak peran dikelas, salah satunya peran sebagai fasilitator. Penekanan bahwa guru sekarang lebih berperan sebagai fasilitator dimaksudkan agar kelas lebih hidup dan bersemangat (Rahmawati \& Suryadi, 2019:50).

Dari wawancara dan observasi lapangan yaitu penerapan teori konstruksivisme dalam pembelajaran daring interaktif berbantu WhatsApp dilaksanakan di SMP Negeri 1 Pabelan Kabupaten Semarang. Observasi dilaksanakan pada tanggal 10-11 Mei 2021 yaitu pembelajaran daring interaktif yang dilaksanakan dengan menggunakan pendekatan scientifik. Hasil yang diharapkan bagaimana pembelajaran daring interaktif dengan menggunakan pendekatan scientifik dapat membuat siswa lebih aktif. Sebagaimana dalam teori konstruksivisme bahwa pembelajaran berpusat pada siswa dengan mengedepankan pengalaman yang dimiliki siswa.

\section{METODE PENELITIAN}

Penelitian ini

menggunakan pendekatan deskriptif kualitatif dengan tujuan memberikan gambaran mengenai penerapan teori konstruktivisme dalam pembelajaran daring interaktif dengan dengan menggunakan pendekatan scientifik yang dilaksanakan di SMP Negeri 1 Pabelan.

Subjek penelitian meliputi kepala sekolah, guru mata pelajaran kelas VIII, dan siswa kelas VIII sebanyak 32 anak. Objek penelitian ini adalah hal-hal terkait dengan pembelajaran daring interaktif.

Tujuan dari penelitian ini adalah mengumpulkan data dengan menggunakan beberapa teknik. Teknik dalam mengumpulkan yaitu dengan observasi, wawancara, atau dokumentasi. Metode ini digunakan untuk memberikan gambaran penerapan teori konstruktivisme dalam pembelajaran daring interaktif dengan dengan menggunakan pendekatan scientifik. Adapun cara melakukan proses analisis dengan pengumpulan data di lapangan, reduksi, penyajian dan menarik kesimpulan.

\section{HASIL DAN PEMBAHASAN \\ Teori Belajar Konstruktivisme}

Belajar menunjukkan kegiatan yang dilakukan oleh seseorang yang disadari atau disengaja. Aktivitas ini mengacu pada keaktifan seseorang dalam menjalankan aspek mental yang memungkinkan terjadinya perubahan dalam dirinya (Pane, 2017:335). Selain itu menurut Trinova (2012:2019) belajar adalah kegiatan yang dilakukan oleh seseorang agar memiliki kompetensi berupa keterampilan dan pengetahuan yang dibutuhkan. Belajar juga dapat dilihat sebagai sebuah proses elaborasi dalam pencarian makna individu.

Konstruktivisme adalah teori tentang bagaimana siswa membangun pengetahuan dari pengalaman, yang unik untuk setiap individu. Konstruktivisme menurut Piaget (1971) adalah sistem penjelasan tentang bagaimana siswa sebagai individu beradaptasi dan meningkatkan pengetahuan. Konstruktivisme merupakan pergeseran paradigma dari behaviourisme ke teori kognitif. Epistemologi behaviourist berfokus pada kecerdasan, domain tujuan, tingkat pengetahuan, dan penguatan. Sedangkan epistemologi konstruktivis berasumsi bahwa siswa mengkonstruksi pengetahuannya sendiri berdasarkan interaksi dengan lingkungannya. Empat asumsi epistemologis merupakan inti dari apa yang kita sebut sebagai "pembelajaran konstruktivis." Pertama, pengetahuan dikonstruksi secara fisik oleh siswa yang terlibat dalam pembelajaran aktif. Kedua, pengetahuan 
secara simbolis dibangun oleh siswa yang membuat representasi dari tindakan mereka sendiri; Pengetahuan dikonstruksi secara sosial oleh siswa yang menyampaikan maknanya kepada orang lain; dan yang terakhir adalah, pengetahuan secara teoritis dikonstruksi oleh siswa yang mencoba menjelaskan hal-hal yang belum sepenuhnya mereka pahami (Singh \& Yaduvanshi, 2015).

Menurut Suardi (2018:164-165) belajar menurut teori kontruktivisme adalah tindakan mencipta suatu makna dari apa yang dipelajari seseorang. Kontruktivis ini merupakan tindakan membangun atau membentuk pengetahuan, sikap maupun keterampilan yang menjadikan ciri dari seseorang. Proses pembentukan ini tidak pernah mencapai titik akhir, namun akan terus mengalami perkembangan.

Teori-teori belajar di atas mengungkapkan bahwa belajar dapat mengubah perilaku, pengetahuan dan keterampilan seseorang.

\section{Pembelajaran Daring Interaktif Berbantu Media Di SMPN 1 Pabelan Kabupaten Semarang}

Pembelajaran seharusnya dilaksanakan secara tatap muka dan ada interaksi antara guru serta siswa. Namun sejak Pandemi Covid-19 pembelajaran dilaksanakan secara daring atau online untuk itu berbagai alternatif ditempuh untuk tetap dapat melangsungkan pembelajaran yang efektif dan semua siswa tidak terbebani. Penggunaan media whatsapp adalah alternatif utama dikarenakan gadget dimiliki semua siswa dan mudah diakses. Dengan tampilan whatsapp yang memiliki banyak fitur seperti mengirim pesan teks, foto, video, video call, voice note, mengirim dokumen dalam bentuk word, excel, powerpoint, dll. Pembelajaran online berbantu whatsapp ini menjadi interaktif yang ditunjukkan dengan adanya interaksi antara guru dan siswa dalam pembelajaran dengan menggunakan pendekatan saintifik. Kegiatan pembelajaran saintifik ada 5 langkah yaitu, mengamati, menanya, mengumpulkan informasi, mengasosiasi, dan mengkomunikasikan. Contoh pada setiap langkah kegiatan pembelajaran guru dapat menggunakan fitur foto, video, pesan teks, atau voice note, mengirim word, PPT, membagikan link, dll.

\section{Media Dalam Pembelajaran Daring Interaktif}

Media merupakan salah satu faktor yang mendukung keberhasilan proses pembelajaran di sekolah karena dapat membantu proses penyampaian informasi dari guru kepada siswa atau sebaliknya. Penggunaan media secara kreatif dapat memperlancar dan meningkatkan efesiensi pembelajaran sehingga tujuan pembelajaran dapat tercapai (Arda dkk, 2013:69). Media juga bisa dikaitkan dengan berbagai platform agar bisa digunakan guru untuk memastikan pembelajaran daring bisa berjalan. Media tersebut dimulai dari sederhana sampai yang tercanggih yaitu antara lain whatsapp, blog, zoom, google meet, you tube, moodle, edmodo, dan banyak yang lain lagi. Whatsapp menjadi pilihan karena secara skill dan knowledge siswa dan guru sudah terbiasa menggunakan teknologi smartphone (Hadi, 2015:43).

\section{Pelaksanaan Pembelajaran Daring Interaktif Menggunakan Pendekatan Scientific}

Fokus penelitian ini dilaksanakan di SMP Negeri 1 Pabelan yang terletak di Jalan Raya Salatiga Bringin Km 08 Kabupaten Semarang, dengan subjek penelitian adalah siswa kelas VIII pada mata pelajaran Bahasa 
Inggris yang berjumlah 32 siswa. Dalam melaksanakan pembelajaran daring atau online yang mengacu pada penerapan konstruktivisme, kegiatan pembelajaran dibagi menjadi tiga tahapan yaitu;

Tabel 1. Tahapan Pelaksanaan konstruktivisme dalam pembelajaran daring

Kegiatan Awal

Kegiatan awal pembelajaran

merupakan kegiatan yang tidak berkaitan langsung dengan materi pembelajaran atau kompetensi yang akan dibahas dalam kegiatan pembelajaran, tetapi merupakan kegiatan yang dilakukan pada awal waktu siswa tiba disekolah (Adinoto, 2019:54).

Komponen kegiatan yang dilaksanakan pada kegiatan awal pelajaran adalah dengan mengaitkan materi pembelajaran saat ini dengan pengalaman siswa atau pembelajaran sebelumnya (apersepsi), memberikan motivasi, menyampaikan tujuan materi pelajaran dan menyampaikan kemampuan yang ingin dicapai. Apersepsi merupakan kegiatan yang akan memotivasi semangat belajar siswa, dan menjadi cara guru untuk dapat menarik minat siswa dengan menampilkan materi yang akan merangsang keingintahuan siswa sehingga materi yang disiapkan guru harus berkaitan dengan kehidupan sehari-hari atau apa yang siswa hadapi saat ini. Dalam implementasinya, apersepsi dalam pembelajaran daring interaktif berbantu gadget dengan aplikasi whatsapp, guru membagikan link video youtube atau gambar, kemudian siswa dapat memahami makna dari apa yang disampaikan.

\section{Kegiatan Inti}

Dalam kegiatan inti pembelajaran, guru banyak mengajukan pertanyaan yang berkaitan dengan definisi, identifikasi yang berhubungan dengan konsep materi pelajaran tertentu. Hal ini dimungkinkan karena dalam kegiatan inti pembelajaran tujuan pembelajaran akan tercapai, sehingga siswa diminta untuk dapat dapat menguasai konsep-konsep tertentu yang berkaitan dengan materi pelajaran (Dewangga, 2018:29).

Kegiatan inti pembelajaran daring di mata pelajaran bahasa Inggris secara khusus ada lima langkah, yaitu:

1) Mengamati, dari hasil penelitian pada kegiatan pembelajaran ini guru memanfaatkan fitur yang ada di whatsapp seperti gambar, video, teks, terlihat dalam kegiatan tersebut siswa dapat melihat, menyimak, mendengar, dan atau membaca. Menurut keterangan guru yang diteliti kegiatan 5M yang pertama menunjukkan banyak siswa yang antusias.

2) Menanya, ditahapan ini siswa melakukan tanya jawab terkait apa yang disampaikan pada kegiatan mengamati. Pertanyaan siswa disampaikan melalui chat, atau voice note.

3) Mencoba atau mengumpulkan informasi, pada langkah yang ketiga guru memberikan tugas yang dibagikan melalui link dan siswa diberi waktu untuk langsung mengerjakan secara online.

4) Mengasosiasi atau menalar, ditahapan yang keempat guru memberikan feedback atau koreksi ke siswa dengan melampirkan bukti screenshoot hasil pekerjaan siswa.

5) Mengkomunikasikan, langkah terakhir dalam pembelajaran ini adalah guru memberi kesempatan siswa untuk bertanya tentang kesulitan yang dihadapi ketika mengerjakan melalui chat atau voice note secara bergantian dengan guru langsung memberikan 
tindak lanjut, dan menyimpulkan materi secara bersama-sama dengan meminta siswa memfoto hasil rangkuman materi dan dibagikan pada chat grup pembelajaran serta guru menambahkan, menjelaskan dengan disertai lampiran materi berupa doc, PPT, e modul, dll.

\section{Kegiatan Akhir}

Kegiatan akhir dalam pembelajaran tidak hanya diartikan sebagai kegiatan untuk menutup pelajaran, tetapi juga sebagai kegiatan menilai hasil belajar siswa dan kegiatan tindak lanjutnya. Kegiatan tindak lanjut harus dilakukan berdasarkan proses dan hasil belajar siswa (Ruhimat, 2010:24). Hasil penelitian pada kegiatan penutup, guru memberikan evaluasi pembelajaran dari awal sampai akhir, pekerjaan rumah terkait materi yang telah dipelajari, dan meminta siswa untuk mempelajari materi yang akan datang.

\section{Faktor Pendukung Penerapan \\ Konstruktivisme Dalam Pembelajaran Daring Interaktif}

Pada pelaksanaan pembelajaran daring interaktif dari segi konstruktivisme, tidak selalu berjalan dengan lancar karena muncul beberapa kendala atau hambatan baik itu dari pihak siswa maupun guru sendiri. Berikut hambatan yang dihadapi:

\section{Sarana}

Sarana adalah sebuah perangkat peralatan, bahan, perabot yang secara langsung digunakan dalam sebuah kegiatan atau aktivitas (Jannah dan Sontani, 2018:95). Sarana yang dimaksud dalam penelitian ini adalah gadget yang dimiliki siswa. Pada pengamatan di lapangan ditemui bahwa tidak semua anak dapat mengakses materi yang dibagikan guru, jika berupa youtube, doc, PPT. Sehingga penyelesaian dari kendala tersebut dalam proses pembelajaran guru harus mampu memberikan solusi. Siswa yang terkendala tidak dapat membuka youtube maka guru dapat membagikan bukti screenshoot atau script untuk membantu siswa.

\section{Model Pembelajaran}

Model pembelajaran konstruktivisme menurut Sujarwanto (2016:90) merupakan model pembelajaran yang berorientasi pada student centered, yaitu memandang siswa sebagai individu aktif dan dapat membangun pengetahuannya sendiri. Fungsi utama dari model pembelajaran konstruktivisme adalah menunjang proses pembelajaran yang efektif yang dilaksanakan guru. Kedudukan model pembelajaran konstruktivisme ada dalam komponen langkah-langkah atau tahapantahapan dalam mengajar merupakan salah satu upaya untuk meningkatkan proses interaksi guru dan siswa dalam kegiatan belajar mengajar (2016:73). Dari hasil penelitian didapati bahwa model pembelajaran $5 \mathrm{M}$ seperti mengamati, menanya, menalar, mencoba dan mengkomunikasikan penyajian materi yang sangat detail pada tiap langkahnya diharapkan memudahkan siswa menangkap pembelajaran sehingga tujuan pembelajaran dapat dicapai dengan maksimal.

\section{Motivasi Belajar}

Motivasi adalah perubahan energi dalam diri seseorang yang ditandai dengan dorongan yang datang dari diri seseorang untuk mencapai tujuan (Maryam, 2016:1). Belajar adalah perubahan dan peningkatan kualitas dan kuantitas perilaku seseorang dalam berbagai bidang yang terjadi sebagai akibat dari interaksi yang terus menerus dengan lingkungannya, di mana belajar bercirikan perubahan tingkah laku yang tidak dapat diamati secara langsung karena perubahan tersebut bersifat potensial, disamping itu perubahan tingkah laku itu bisa 
dari hasil latihan atau pengalaman, dan pengalaman itu akan memberikan dorongan untuk mengubah tingkah laku (Nidawati, 2013:26-27). Motivasi dan belajar adalah dua hal yang tidak bisa dipisahkan. Dalam kegiatan pembelajaran dibutuhkan motivasi yang mendukung belajar siswa. Pembelajaran yang dilandasi oleh motivasi yang kuat akan memberikan hasil belajar yang lebih baik. Sebagaimana diketahui belajar adalah proses orang memperoleh berbagai kecakapan, ketrampilan dan sikap (Maryam, 2016:92). Dalam penelitian ini guru sudah memotivasi siswa dalam pembelajaran daring dengan memberikan pujian setelah menjawab pertanyaan dengan emoticon yang ada di chat grup atau dengan menciptakan suasana kelas daring yang menyenangkan.

\section{KESIMPULAN}

Konstruktivisme adalah teori tentang bagaimana siswa membangun pengetahuan sendiri dari pengalamannya. Dalam membangun pengetahuan tersebut harus mempunyai dasar bagaimana membuat dan mempunyai kemampuan untuk menguji, menyelesaikan persoalan, mengekpresikan ide sehingga diperoleh konstruksi yang baru.

Penerapan teori konstruktivisme dalam pembelajaran daring selain menggunakan media dan model pembelajaran $5 \mathrm{M}$ dalam penelitian ini diharapkan mampu membuat siswa lebih aktif dan guru sebagai fasilitator menjadi lebih inovatif sehingga tujuan pendidikan dapat tercapai dengan maksimal meski ditengah pandemi Covid-19.

Dalam pelaksanaan pembelajaran daring harus didukung pula beberapa hal yaitu terkait dengan sarana, model pembelajaran, dan motivasi siswa. Sarana dipilih dengan menyesuaikan tingkat kemampuan siswa. Guru dapat menggunakan model pembelajaran agar siswa tidak bosan dan pembelajaran menjadi interaktif. Hal tersebut harus diimbangi dengan motivasi dari siswa dan bagaimana cara guru memotivasi.

\section{DAFTAR RUJUKAN}

Adinoto, P. (2019). Pengaruh Kegiatan Awal Pembelajaran, Disiplin Belajar Dan Motivasi Belajar Terhadap Prestasi Belajar. Jurnal Imiah Pendidikan Dan Pembelajaran, $3(1), \quad 53$. https://doi.org/10.23887/jipp.v3i1.17110

Arda, Saehana, S., \& Darsikin. (2013). Pengembangan Media Pembelajaran Interaktif Berbasis Komputer Untuk Siswa Smp Kelas Viii. E-Jurnal Mitra Sains, 3(1), 69-77.

Dewangga, G. S. (2018). Aspek Pengetahuan Dalam Tuturan Bertanya Guru Bahasa Indonesia Dalam Proses Pembelajaranaspek Pengetahuan Dalam Tuturan Bertanya Guru Bahasa Indonesia Dalam Proses Pembelajaran. Diksi, 25(1). https://doi.org/10.21831/diksi.v25i1.18850

Dewi, R. E. (2018). Metode Pembelajaran Modern Dan Konvensional Pada Sekolah Menengah Atas Erni. Jurnal Ilmu Pendidikan, Keguruan, Dan Pembelajaran, 2(April), 29. https://www.readcube.com/articles/10.268 58\%2Fpembelajar.v2i1.5442

Hadi, B. (2015). Pemanfaatan Aplikasi Whatsapp Pada Pembelajaran. Pengembangan ICT Dalam Pembelajaran Universitas Sebelas Maret, November, 36-44.

Ibrahim. (2017). Perpaduan Model Pembelajaran Aktif Konvensional (Ceramah) dengan Cooperatif (Make-a Match) untuk Meningkatkan Hasil Belajar Pendidikan Kewarganegaraan. Jurnal Ilmu Pendidikan Sosial, Sains, Dan Humaniora, 3(2), 199 212.

Jannah, S. N., \& Sontani, U. T. (2018). Sarana Dan Prasarana Pembelajaran Sebagai Faktor Determinan Terhadap Motivasi Belajar Siswa. Jurnal Pendidikan Manajemen Perkantoran, 3(1), 210. https://doi.org/10.17509/jpm.v3i1.9457

Maryam, M. (2016). Pengaruh Motivasi dalam Pembelajaran. Lantanida Journal, 4(2), 88-97. https://jurnal.arraniry.ac.id/index.php/lantanida/article/do 
wnload/1881/1402\%0Ahttps://media.neliti. com/media/publications/287678-pengaruhmotivasi-dalam-pembelajarandc0dd462.pdf

Nidawati. (2013). tingkah laku yang tidak bisa secara langsung dapat diamati karena perubahan tersebut bersifat potensial, disamping itu perubahan tingkah laku itu bisa berupa dari hasil latihan atau pengalaman, dan pengalaman itulah yang akan memberikan dorongan untuk men. 1 , $13-28$.

Pane, A. (2017). Belajar dan Pembelajaran Aprida Pane Muhammad Darwis Dasopang. Fitrah, 03(2), 333-352.

Rahmawati, M., \& Suryadi, E. (2019). Guru sebagai fasilitator dan efektivitas belajar siswa. Jurnal Pendidikan Manajemen Perkantoran, 4(1), 49. https://doi.org/10.17509/jpm.v4i1.14954

Ruhimat, T. (2010). Prosedur Pembelajaran. Universitas Pendidikan Indonesia, 1-30. http://file.upi.edu/Direktori/FIP/JUR._KU RIKULUM_DAN_TEK._PENDIDIKAN/ 195711211985031-

TOTO_RUHIMAT/Prosedur_pembelajara n_di_SD.pdf

Singh, S., \& Yaduvanshi, S. (2015). Constructivism in Science Classroom:
Why and How. International Journal of Scientific and Research Publications, 5(3), 1-5. www.ijsrp.org

Suardi, M. (2018). Belajar dan Pembelajaran (1st ed.). Deepublish.

Sujarwanto, -. (2016). Penerapan Model Pembelajaran Konstruktivisme Pada Materi Ciri-Ciri Mahluk Hidup Di Kelas Iii a Sd Negeri Keputran. Mimbar Sekolah Dasar, 3(1), 69-80. https://doi.org/10.17509/mimbarsd.v3i1.2357

Suparlan, S. (2019). Teori Konstruktivisme dalam Pembelajaran. Islamika, 1(2), 7988.

https://doi.org/10.36088/islamika.v1i2.208

Tahrun. (2021). PENGEMBANGAN MODEL PEMBELAJARAN BERBASIS KONSTRUKTIVISME PADA KELAS MAYA. 34-45.

Trinova, Z. (2012). Hakikat Belajar Dan Bermain Menyenangkan Bagi Peserta Didik. Al-Ta Lim Journal, 19(3), 209-215. https://doi.org/10.15548/jt.v19i3.55

Tuti, F. M., Musriandi Riki, \& Suryani Linda. (2020). Covid-19: Penerapan Pembelajaran Daring Di. Dedikasi Pendidikan, $\quad$ 8848(2), 193-200. 